\title{
Alaska's Economy: The First World War, Frontier Fragility, and Jack London
}

\author{
Lee Huskey \\ University of Alaska Anchorage
}

\begin{abstract}
The two world wars had dramatically different effects on the Alaska economy. The military build-up during the Second World War created an economic boom and laid the foundation for the modern Alaska economy. The First World War contributed to an economic decline that followed the dramatic expansion of mining activity and population in the first decade of the century. The boom and bust story is familiar to anyone interested in the economies of frontier regions. The frontier is assumed to be a fragile economy dependent on the economic fortunes of its resource industries. The economy expands and contracts with staples production. The support sector plays a passive role in economic growth and development of the frontier. Jack London suggested a different role for firms in the frontier's support sector. He hypothesized that in a staples bust some portion of this support sector would remain. This remainder would change the frontier economic environment, providing services and reducing costs for the future. The supporting industries become an active participant in a virtuous cycle of economic development on the frontier. The First World War provides a natural experiment to test Jack London's hypothesis. This article looks at the effects of the decline in Alaska's staples industries, which started in the First World War, on the territory's support sector. Did the supporting industries simply collapse like gold, copper, and fishing? Or did these industries seem resilient in the face of the staples decline? Census and Polk Directory data are used to test this hypothesis. This article is part of a special collection of papers originally presented at a conference on "The North and the First World War," held May 2016 in Whitehorse, Yukon.
\end{abstract}

The Northern Review 44 (2017): 327-346 


\section{Introduction}

The two world wars had dramatically different effects on the Alaska economy. The buildup of the military economy during the Second World War created an economic boom and laid the foundation for the modern Alaska economy (Rogers 1962). The First World War, on the other hand, contributed to Alaska's first modern economic bust. Cole and Rasmuson $(2000,57)$ called it "the worst economic collapse in Alaska History." Between the two wars, the Alaska economy remained in the doldrums.

The economic bust that began with the First World War followed a dramatic boom in mining activity and population in the first decade of the century. This boom-bust story is familiar to anyone interested in the economies of frontier regions. In this story, the staple or resource sector of the economy is the driving force. The boom in staples production causes a parallel expansion of those industries that support the population and firms working in the staples sector. This supporting sector includes such businesses as barbers, butchers, furniture makers, and undertakers. They are drawn to the territory by the spending and re-spending of money earned in resource industries.

The boom-bust story describes the frontier as a fragile economy dependent on the economic fortunes of its resource industries. The supporting industries contract when production and income in the staples sector decline. They simply react to the collapse of their existing market. In a bust, production in the supporting sector parallels the collapse in staples production. In this story, the support sector plays a passive role in economic growth and development of the frontier.

Jack London (1900) suggested a different role in the frontier's development for firms in the support sector. London hypothesized that the resource boom would leave behind a more resilient economy. He suggested that the support sector of the frontier economy would not completely collapse in a staples bust and that some portion of this sector would remain. This remainder would change the frontier economic environment, providing services and reducing costs for future staples activity. In this view, the supporting industries become an active participant in a virtuous cycle of economic development on the frontier.

The Alaska Territory's leading staples industries-gold, fish, and copper-each experienced the First World War differently, but for each the war marked the beginning of a period of decline. Cutbacks in production and employment resulted in people leaving the territory. 
Jones $(2010,48)$ observed that the notable exodus of population "had a marked impact on the shops, services and trades." This article looks at the effects of the decline in Alaska's staples industries on the territory's shops, services, and trades. Did the supporting industries simply collapse like gold, copper, and fishing? Or did these industries seem resilient in the face of the staples decline? The First World War provides a natural experiment to test this economic response and Jack London's hypothesis. That is the purpose of this article.

The next section of the article will summarize the economic consequences of the First World War for the Alaska economy. This section will be followed by a discussion of the role of the supporting industries in the frontier economy and the hypothesis of economic resilience. This will be followed by a test of this hypothesis using data about the period from the US Census in 1910 and 1920, and the Polk Directories from 1915-1916 and 1923-1924. The final section of this article will discuss how these observations from early in Alaska's history may be relevant to the discussion of sustainable resource development in the North today.

\section{The First World War and the Alaska Economy}

The second decade of the twentieth century was a time of economic optimism in Alaska. Coal and the construction of the Alaska Railroad represented the promise for the territory's future. Alaska's coal resources, which were assumed to exceed those of Pennsylvania, were opened to leasing in 1914. The Pacific merchant and naval fleets were a waiting market (Cole and Rasmuson 2000). Railroad construction began in 1914, creating jobs and new communities; at its peak there were 4,500 jobs in construction of the line (Naske and Soltnick 1987). The railroad provided the key that promised to open the potential of Alaska's interior to the world economy.

Unfortunately, the promise was short-lived. The Navy determined in the early 1920s that low quality and high costs eliminated their interest in the coal fields in Southcentral Alaska (Cole and Rasmuson 2000). The Alaska Railroad was eventually completed in 1923, but human resources and materials were curtailed during the war and this slowed its completion. While it created construction and operations jobs throughout the period, the railroad failed to generate a rush to discover and develop Alaska resources (Haycox 2002).

The war years treated Alaska's three main industries differently. The war was good to the copper and fishing industries; increased war-related demand for each product resulted in expanding production. Copper prices 
reached their highest levels in a century in 1916, and the fish pack in 1918 was almost three times what it was in 1910 (Cole and Rasmuson 2000). The wartime boom in the fishing industry had limited effect on the Alaska population and economy since there was little resident employment in the fishing industry. The salmon packers brought crews from Outside for the fishing season (Naske and Soltnick 1987).

Gold production, however, went the other way; production fell in value by almost half between 1910 and 1918. The profitability of gold mining was limited by an inflexible legal price of gold and rapidly rising production costs. Wartime inflation tripled the cost of mining as labour and material became more expensive (Cole and Rasmuson 2000). The war also had indirect effects on the economy's collapse and the population exodus. Military service and high wages in wartime industries outside Alaska attracted its large population of single men. The rapid rise in prices and the shortage of shipping to export products and bring materials to Alaska made living and doing business more difficult. Wartime spending and high costs likely contributed to the decline in investment in the state. Finally, the delay in appropriations for the Alaska Railroad reduced employment opportunities (reflections of Andrew Stevenson as referenced in Cole and Rasmuson 2000, 86)

The war years saw a substantial departure of population from Alaska. The White population of the territory fell by 50\% between 1916 and 1918 (Cole and Rasmuson 2000). Anchorage, Alaska's most recent boom town, lost around 3,000 people (Jones 2010). The territory's population fell by 14\% between the 1910 Census and the 1920 Census - from 55,000 to 47,000 (Naske and Soltnick 1987). This exodus presented a challenge to businesses in the support sector of the economy since it represented a decline in the market for their products.

The post-war period treated the Alaska economy no better than the war years. After the war, Alaska commerce declined by $50 \%$ (Cole and Rasmuson 2000). Both copper and fishing suffered from declining prices that reflected the short post-war recession in the United States and the longer recession in commodity industries (Walton and Rockoff 2010). With the end of the war and the recovery of European agriculture, the demand for both copper and fish fell. In addition, overfishing during the war resulted in a significant decline in the salmon runs; the salmon pack fell by 60\% between 1918 and 1921 (Cole and Rasmuson 2000).

The First World War ended the "gold rush" boom in the North and began the long-term stagnation in the Alaska economy. As described by historian Terrence Cole: “The First World War disrupted Alaska's 
economy as no outside event had ever done before, and set in motion a downward spiral that continued for years. The traumatic loss in Alaska of businesses, jobs, population, capital, and confidence, equaled the darkest days of any downturn in American history. The Great Depression of the 1930s left Alaska relatively unscathed in part because the economy and population of the territory had already collapsed a dozen years earlier during the Great War" (Cole and Rasmuson 2000, 83). The First World War initiated a dramatic and long-term decline in Alaska's resource industries, which demonstrated the fragile nature of staples driven economic booms.

\section{Jack London and the Fragile Frontier Economy}

The boom-bust story describes a fragile frontier economy. Economic wellbeing in this story depends entirely on production in the staples or resource industries. The shops, services, and trades that support the population and industry drawn to the frontier by staples activity simply react and follow resource production. This dependency means the supporting industries follow the boom-bust cycle of staples production. This section discusses the boom-bust story of the economy then introduces an alternate story of a less fragile frontier, first presented by Jack London.

This boom-bust model fits neatly into the widely-used economic base models of regional growth (Krikelas 1992). In this model, external demand for the products of a region drive its economic growth. The basic sector of the economy serves this external demand. The support sector serves a local market that grows or declines in response to changes in the basic sector. In the simple model, the relationship between these sectors of the economy is described mechanically by a multiplier where a certain number of support sector jobs are created for each basic sector job. In the economic base model, the determinants of growth are external and level of activity in the support sector is directly related to size of the basic sector. The support sector of the region's economy plays a passive role and simply reacts to changes in the basic sector.

The fragile frontier economy of the boom-bust story reflects the importance of external demand for its natural resources and the passive nature of the supporting industries. Staples production is governed solely by external markets and nature. The products of harvesting, farming, and mining are sold into national or international markets. Factors outside the frontier will determine the demand for these products. Staples activity also reflects the physical limits of the resource; frontier production decisions are affected by weather, geology, and transport costs. Price movements in external markets and the discovery or exhaustion of the local resource 
base drive the frontier economy in its cycle of boom and bust. The shops, services, and trades are passive actors in this tale. They expand when the staples industries expand, and follow their market out of the territory when the staples industries contract. The size of this sector of the frontier economy depends entirely on the health of the staples industries.

Jack London took on the idea of the fragile frontier in his essay "The Economics of the Klondike" (1900). His primary purpose in this essay was to refute the critics of the Klondike Gold Rush. Others had described the movement of thousands to the Klondike gold fields as "a poor business decision" and "an example of human folly." London acknowledged that the costs of seeking and producing the gold in the Klondike were greater than the value of the gold removed. However, he stated, the individual loss for the stampeders had "been of inestimable benefit to the Yukon country, to those who will remain in it and to those yet to come."

London's argument had three parts. First, the economic environment was changed by what went before.

But henceforth famine will be only a tradition in the land. The Klondike rush placed hundreds of steamers on the Yukon, opened navigation of its upper reaches and lakes, put tramways around the unnavigable Box Canyon and White Horse rapids, and built a railroad from the salt water at Skagway across the White Pass to the head of steamboat traffic on Lake Bennett. (73)

Second, the changes in the economic environment changed the cost conditions in the region.

Conditions will become normal and the Klondike just enter upon its true development. With necessaries and luxuries of life cheap and plentiful, with the importation of machinery which will cheapen many enterprises and render many others possible ... when a sack of flour may be bought for a dollar instead of fifty, and other things in proportion, it is apparent how great a fall the scale of pay can sustain. (73)

Finally, the reduction in costs would make more activity profitable.

Living expenses being normal, a moderate wage will be possible. Nor will laborers fail to hasten there from the congested labor markets of the older countries. This is turn, will permit the employment on a large scale of much of the world's restless capital now and seeking investment. (73) 
The new Klondike, the Klondike of the future, will present remarkable contrasts with the Klondike of the past. Natural obstacles will be cleared away or surmounted, primitive methods abandoned, and hardship of toil and travel reduced to the smallest minimum. Exploration and transportation will be systematized ... The frontiersman will yield to the laborer, the prospector to the mining engineer, the dogdriver to the engine driver, the trader and speculator to the steady going modern man of business. (74)

The real benefits of the Klondike Gold Rush couldn't be counted simply as the gold removed from the field. The real benefits came in the changes brought to the country, which opened the region to future economic growth. In London's story, the supporting sector was not a passive actor in regional economic growth, but an active participant.

In this essay Jack London disagreed with the description of the fragile frontier economy. He suggested that frontier resource booms would leave something behind after a bust. The boom associated with the Klondike Gold Rush changed the economy of the North by attracting trading and transport firms that supported the miners. These firms didn't all leave when the boom died; those that stayed supported new resource development throughout the country. These firms played an active role lowering costs and expanding opportunities. According to London, it was the shops, services, and trades that provided the basis for making the northern economy more resilient.

The active role of the support sector as a source of regional resilience is supported by others. Haycock (2002) describes Alaska's frontier economic growth as a series of booms and plateaus with the economy, over time, moving to higher and higher plateaus. This is consistent with an active supporting sector remaining when a resource boom has died, and preparing the region for the next opportunity. Belich (2010) turns the story of the resource boom on its head with his examination of historic frontier booms around the world. He suggests the development of the supporting industries and infrastructure caused the booms and paved the way for the resource development. Finally, Thompson (1965) hypothesized that a developed supporting sector provided one element of his "urban size ratchet" that limited the decline in big cities when their major industries went "bust." These urban supporting sectors kept costs low and provided opportunity for continued economic exchange. Each of these observers identifies the supporting industries as significant actors in creating a resilient economy. 


\section{Testing the Jack London Hypothesis}

"The Economics of the Klondike" provides a hypothesis about the role of the supporting industries in frontier economic growth. The Jack London hypothesis could be stated in two parts as: Resource development changes the local economy in ways that (1) last beyond a particular resource boom; and (2) encourage future economic activity. More specifically, the hypothesis would emphasize the role of the supporting industries: Resource development changes the support sector in ways that (1) last beyond a particular resource boom; and (2) encourage future economic activity. The First World War economic bust provides a natural experiment for testing this hypothesis. This section tests the first portion of the Jack London hypothesis using the pattern of Alaska economic change around the First World War.

The war and the years that followed produced a bust in the gold, copper, and fishery industries that followed the pre-war boom times. The hypothesis would predict that the supporting industries did not experience the same degree of economic decline as the staples industries. The test asks if changes in the supporting industries simply mirror this decline in resource production. If these industries mirror the decline, there would be no support of the Jack London hypothesis. Rejecting the idea of a parallel pattern of change in the supporting industries would be consistent with, and would support, London's hypothesis.

Two sources of data are available for testing the hypothesis. Both allow the description of changes in the support sector of the economy that followed the First World War decline in the Alaska staples sector. The United States Census in 1910 and in 1920 provide data on the Alaska economy before and after the First World War. The census describes the occupational structure of the Alaska population. The size and distribution of employment by occupation in these two years allows a comparison of the structure of the pre- and post-war economy.

The Polk Business Directories for 1915-1916 and 1923-1924 are another source of information about the Alaska support sector's response to the First World War bust. City business directories have been produced in North America by a number of companies starting in the eighteenth century (Library and Archives Canada 2015). The purpose of the directories was to promote communication between buyers and sellers; businesses in each community advertised their services and locations to potential customers.

Businesses in the Polk Directory are listed by general business categories. The Polk listings can be used to describe the economy by the number of firms in each business category. Comparison of the number 
of firms by business category in the 1915-1916 and 1923-1924 directories shows the economic changes following the First World War economic bust. The Polk and census data provide two different sources for looking at the changes in the Alaska economy in the period around the First World War.

Both data sources provide a look at the Alaska economy before and after America's entry into the war. Both also end after the peaks in gold and copper production. The timing of the beginning years, however, is not perfect. The 1910 Census was conducted before the start of Alaska Railroad construction and the settlement of Anchorage. The Polk canvass for the 1915-1916 directory occurred during the city's initial settlement. The consequence of growth and settlement of Anchorage from the change in the support sector can't be easily isolated.

The census is a well-used source of historic data, but any data collection in the vast, sparsely settled territory of Alaska offers questions about collection methods and the timing. The private Polk canvas might be even more suspect than the census. However, Polk Directories are commercial, profit-making ventures. As with the census, Polk information was collected by door-to-door canvass with the goal of 100\% collection (Hanel 1975). Accuracy and complete coverage were important for Polk because they were concerned about future sales. Unlike census respondents, businesses had an incentive to be in the directories, since the directories provided advertising and a connection to potential customers. The census and Polk enumerators would have had similar difficulties canvassing over the vast area of Alaska with its limited transportation and seasonal weather extremes. Using two separate data sources, each with potential limitations, provides a check on the role that data plays in testing the hypothesis.

Comparing occupational employment from the 1910 and the 1920 Census offers support for the Jack London hypothesis. Figure 1 shows that, while employment in each major occupational sector fell over this period, employment in the staples industries fell at a more dramatic rate than in the supporting industries. The staples industries include fisheries, farming, forestry, mining, and manufacturing. Between 1910 and 1920 this sector shrank by more than $40 \%{ }^{1}$ Of the supporting industries, only Domestic Services and Transportation each fell by more than $20 \%$. The remaining supporting industries declined by less than $10 \%$. The rate of decline in both Trade and Professional Services was just over onetenth of the fall in the staples industries. According to census data, the First World War economic bust in the staples sector was not mirrored in Alaska's supporting industries. 


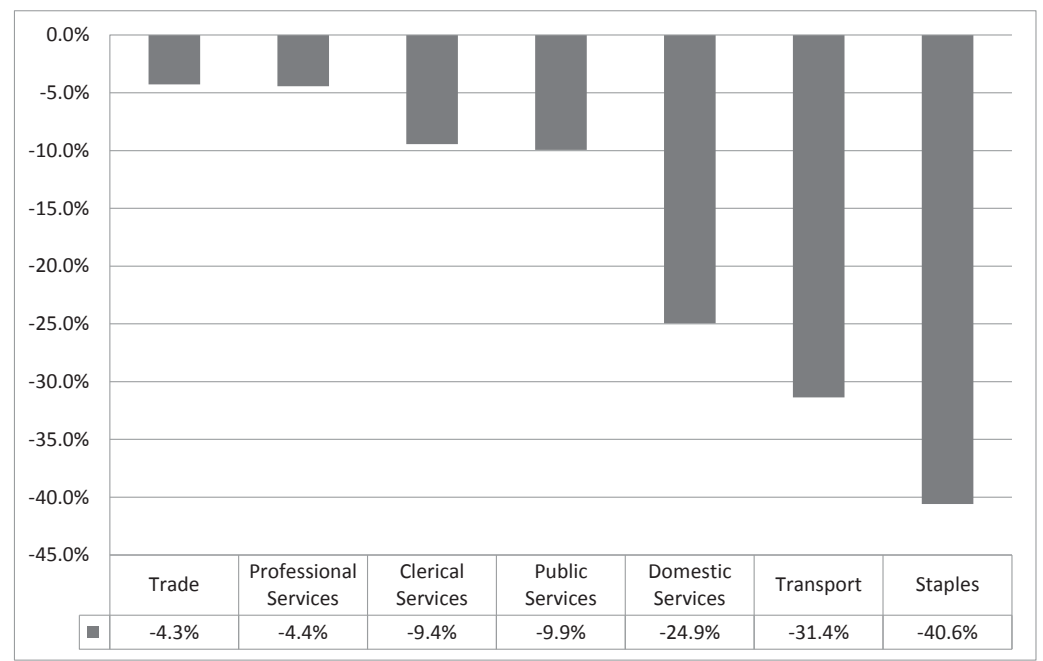

Figure 1. Rate of Alaska employment change 1910-1920. Source: US Census, 1910 and 1920

The structure of the post-bust Alaska economy differed from its structure in 1910 as illustrated in Figure 2. The staples industries continued to play a dominant role with $56 \%$ of total employment in the 1920 Alaska economy. However, the share of the staples industries in total employment fell from $63 \%$ in 1910 . This meant that the supporting industries all increased their share of employment. Domestic Services and Trade each increased their share of total employment by more than the other parts of the support sector. The economic environment in Alaska was changed by the early twentieth century "mining boom," a change that survived the economic bust of the First World War.

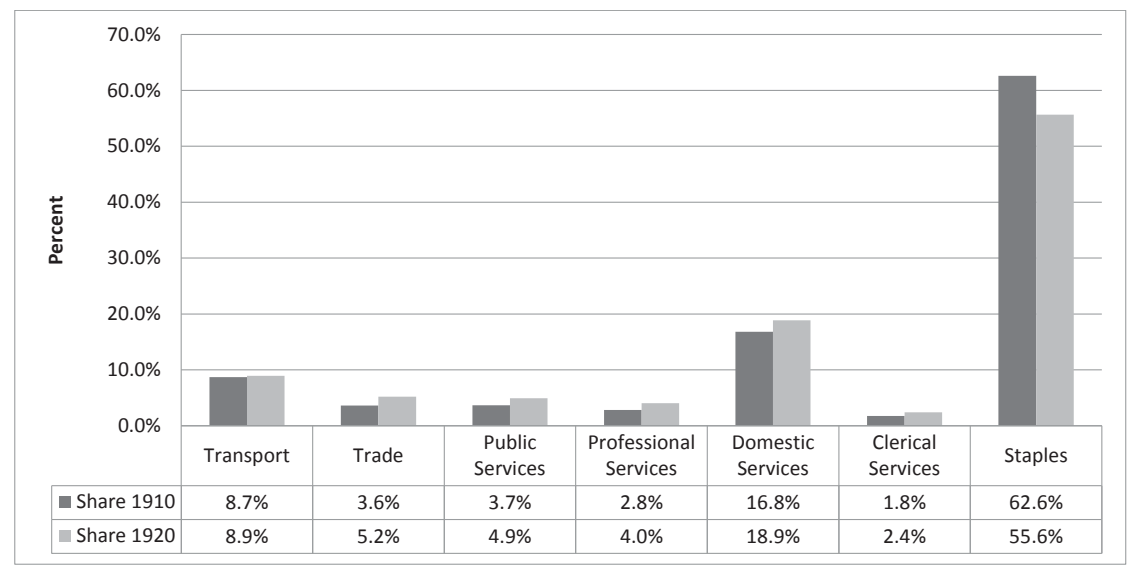

Figure 2. Share of total employment, 1910, 1920. Source: US Census, 1910 and 1920 
The census provides employment numbers in more specific occupational categories for each of the seven larger groups in Figure $1 .^{2}$ Examining the change in occupations at this more detailed level provides a picture of the type of economy left behind in the mining bust. Table 1 shows the detailed occupations that expanded their share of Alaska's employment. All of the detailed support occupations listed in both 1910 and 1920 expanded their relative presence in the economy with three exceptions. Prohibition introduced in the United States in 1920 explains the decline in Bartenders and Saloon keepers; Non-store Clerks is the third support occupation that declined relative to total employment. Blacksmiths, Engineers, and Machinists were detailed occupations within Manufacturing that expanded their share of the total employment. The detailed occupations that expanded seem to be those that would provide general services to businesses or serve a settled population.

Table 1. Occupations that increased their share of the Alaska Employment, 1910-1920

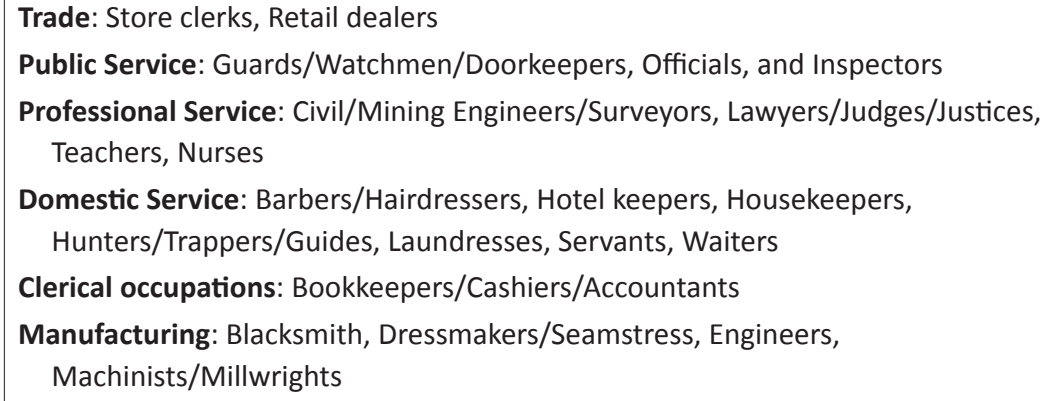

Source: US Census, 1910 and 1920

With more than 300 different business types listed in either year, the Polk Directories provide a more detailed description of the support sector than the census. The directories provide an account of the Alaska economy before and after America's entry into the First World War. The Jack London hypothesis can be tested by calculating the change in the number of firms in each business category. This change can be compared to the change over this same period in the staples sector and the overall economy. A relative increase in the number of firms in a business category would be consistent with the hypothesis. ${ }^{3}$

The primary difficulty with using the Polk data to test the Jack London hypothesis is the lack of any easy measure of staples or overall economic activity between the years 1915 and 1924. Two alternative measures were developed. The first was the change in the real value of mineral production between 1913 and 1923. Starting in 1913 eliminates the effect of the spike 
in the value of mineral production that occurs in 1916 as a result of the increased value of copper. Over this period, the real value of mineral production declined by about $40 \%{ }^{4}$

The second measure used was an estimate of the change in the nonIndigenous population between 1915-1916 and 1923-1924. The census provides estimates of this population for 1910, 1920, and 1930. To estimate the 1915-1916 population, the annual rate of change in the non-Indigenous population was assumed to be constant through the decade 1910-1920. This annual growth rate was applied, starting in 1910, to achieve an estimate for this population in 1915 and 1916. The 1915-1916 for this population average was 32,820. The 1923-1924 average non-Indigenous population was estimated in a similar manner to be 29,068 . The estimated decline in Alaska's non-Indigenous population was $11 \%$.

The change in the number of firms listed in each business category describes the support sector response to the First World War economic bust on a micro level. Business categories that experienced a decline in the number of firms of less than $40 \%$ grew relative to staples production. Business categories with decline of less than $11 \%$ increased the per capita size of that category. The portion of business categories that increased their share of economic activity relative to the staples sector will be the test of the Jack London hypothesis.

Two adjustments were necessary before the Polk data could be used to examine change over the time period. The first was geographic. While the earlier directory included a number of smaller mining towns, the 1923-1924 directory included only the larger towns. Alaska towns in the 1923-1924 directory included Anchorage, Cordova, Fairbanks, Juneau, Ketchikan, Nenana, Nome, Petersburg, Seward, Skagway, Valdez, and Wrangell. The first adjustment was to count only businesses in these towns in the first directory.

The second adjustment was to the number of categories. There were twenty-two business categories listed in 1915-1916 that weren't in the second directory, and thirteen that were added in the second; these are listed in Table 2. These differences may simply reflect the process of data collection with businesses or canvassers identifying the appropriate categories. These might also include renaming categories or grouping smaller categories. Technology and regulation change may explain other changes. Finally, the changes might reflect the change from a booming frontier to a more settled territory. Table 2 speculates on the reasons for these changes. Without certainty about the movement of firms between 
these categories, the best alternative was to leave these out of our comparison.

The Polk Directories listed 307 different business categories in either year. Removing smaller communities' listings, special contracted listings, staples producers, and business types appearing in only one directory left only 112 business categories representing the support sector. More than two-thirds of the support-industry business categories (75 categories) expanded relative to the change in mineral production. Of these, fifty-five business types, almost half of the total, declined less than the $11 \%$ decline of Alaska's non-Indigenous population. These fifty-five businesses types accounted for almost two-thirds of the 1,788 support sector businesses in the 1924-1925 directory. A significant share of the support sector did not mirror the decline found in measures of the total economy and the minerals industry after the First World War. This pattern is consistent with the first part of the Jack London hypothesis.

Table 3 describes the actual business classifications by their relative growth. The first column lists the business types that declined relative to staples production. These types also declined in per capita terms. The next two columns record the business categories that increased relative to staples production. Those that also increased in per capita terms are identified. The business categories were sorted into three groups: goods providers, service providers, and makers or those businesses that produced things.

Table 2. Difference in business categories, Polk Directories 1915-1916 to 1923-1924

\begin{tabular}{ll}
\hline $\begin{array}{l}\text { Categories dropped in the 1923-1924 } \\
\text { directory }\end{array}$ & $\begin{array}{l}\text { Categories added to the 1923-1924 } \\
\text { directory }\end{array}$ \\
\hline $\begin{array}{l}\text { Renaming/Grouping: Ladies' } \\
\text { furnishings, Shipping and commission, }\end{array}$ & $\begin{array}{l}\text { Renaming/Grouping: Women's } \\
\text { furnishings, Transportation companies }\end{array}$ \\
$\begin{array}{l}\text { Freight packing and transfer, Lighterage, } \\
\text { Gas engines, Moving Picture Theaters }\end{array}$ & $\begin{array}{l}\text { Technology/Regulation: Auto accessories } \\
\text { and supplies, Auto garages/livery, Taxicabs, } \\
\text { Soft drink manufacturers }\end{array}$ \\
$\begin{array}{l}\text { Technology/Regulation: Brewers, } \\
\text { Saloons, Roadhouses, Piano tuners, }\end{array}$ & $\begin{array}{l}\text { Settlement: Home builders, Plumbers } \\
\text { Livery stables, Wagon makers }\end{array}$ \\
$\begin{array}{l}\text { Settlement: Assayers, Civil engineers } \\
\text { and surveyors, Notaries Public, Safe } \\
\text { deposit vaults, Saw Mills, Traders, } \\
\text { Umbrella dealers, Boarding houses, }\end{array}$ & $\begin{array}{l}\text { wholesalers, Shoe shine parlours } \\
\text { Furnished rooms, Lodgings }\end{array}$ \\
\hline $\begin{array}{l}\text { Source: Polk \& Co, 1923-24 and 1915-1916 } \\
\end{array}$
\end{tabular}


Table 3. Change in businesses by categories, Polk Directories, 1915-1916 to 1923-1924

\begin{tabular}{|c|c|c|}
\hline \multirow{2}{*}{$\begin{array}{l}\text { Declined relative to } \\
\text { staples production } \\
\text { Goods }\end{array}$} & \multicolumn{2}{|c|}{ Increased relative to staples production } \\
\hline & Goods & Public buildings/halls* \\
\hline Livestock dealers & Grocers retail* & Dyers and cleaners* \\
\hline Fish retail & Music merchandise* & Hotels * \\
\hline Harness and saddlery & Department stores* & Theaters* \\
\hline Wallpaper stores & Electric appliances and & Music teachers* \\
\hline Booksellers/stationers & supplies* & Hair dressers* \\
\hline Cigar/Tobacco retail & Hardware retail* & Rentals* \\
\hline Jewelers retail & Shoe retail* & Auto repair* \\
\hline Coal shippers & Dry goods retail* & Mechanical engineers* \\
\hline Hay, grain feed stores & Paints and glass* & Physicians \\
\hline Second-hand goods & News dealers* & Restaurants \\
\hline \multirow[t]{2}{*}{ Grocers wholesale } & Photographers' supplies* & Lawyers \\
\hline & Notions retail* & Newspapers \\
\hline Services & Oil companies* & Manufacturing agents \\
\hline Stenographers & Curios* & Commercial bodies \\
\hline Baths & Sporting goods* & Barbers \\
\hline Docks and wharves & Stoves and ranges* & Photographers \\
\hline House/sign painters & Builders supplies* & Undertakers \\
\hline Guides & Pictures and frames* & Laundries \\
\hline Real estate & Coal wholesale/retail* & Opticians \\
\hline Insurance agents & Automobiles* & \\
\hline Nurses & General merchandise* & Makers \\
\hline Publishers & Kodaks* & Dress makers* \\
\hline Libraries/reading rooms & Crockery/glass sales* & Machinists* \\
\hline Bowling alleys & Hats* & Coopers* \\
\hline Brokers & Millinery retail & Electricians* \\
\hline Billiards & Typewriters sales & Gun and locksmiths* \\
\hline \multirow[t]{2}{*}{ Storage } & Furniture dealers & Tailors* \\
\hline & Confectionery retail & Bakers* \\
\hline Makers & Clothing retail & Dairies* \\
\hline Cigar makers & Meat markets & Greenhouses* \\
\hline Blacksmiths & Drugs retail & Lumber manufacture / \\
\hline Stage lines & & dealers* \\
\hline Printers & Services & Butter and eggs sales* \\
\hline Soda bottlers & Clergymen* & Welding* \\
\hline Boat builders & Chiropractors* & Box manufacturers* \\
\hline Building contractors & Osteopaths* & Poultry breeders* \\
\hline Tin-copper-sheet-iron works & Ship chandlers* & Loggers \\
\hline Bookbinders & Banks* & Ice manufacture \\
\hline Cabinetmakers & Express dray transfer men* & \\
\hline Upholsterers & Hospitals* & ${ }^{*}$ Also increased relative \\
\hline Shoemakers and repair & Telegraph and telephone* & to non-Indigenous \\
\hline & Dentists* & population \\
\hline
\end{tabular}

Source: Polk \& Co, 1923-24 and 1915-1916 
The Polk Directory results are, for the most part, consistent with the census findings. Hotels, Hairdressers and Barbers, Mechanical Engineers, Dressmakers, Machinists, and Lawyers increased their relative importance in both the Polk and the census. Only Nurses and Blacksmiths had opposing results in the two sources. Differences in what is counted may explain this. The census counts employment by occupation while the Polk counts business firms by type. The number of nurses and blacksmiths could increase while the number of independent firms offering those services declined as long as other businesses hired more nurses or blacksmiths. This distinction may also help to explain why certain occupations, such as Bookkeepers, Servants, and Guards have no equivalent in the Polk results. Occupations like teachers and judges are also likely to be employed by the public sector, which was not included in the Polk Directories.

The majority of the goods-providing business types (56\%) experienced an increase relative to the change in the non-Indigenous population and mineral production. Less than $30 \%$ of goods providers experienced a decline relative to population and mineral production. Of maker-business types, $43 \%$ experienced decline relative to both population and mineral production, while $50 \%$ increased relative to both population and mineral production. Business types that declined relative to both population and mineral production were relatively evenly divided among goods providers (30\%), service providers (38\%), and makers (32\%). Goods and services providers dominate the business types that increased relative to population and mineral production with $75 \%$ of the total.

How can this pattern of change be explained? The decline in the staples industries would likely reduce the demand for goods and services used directly in the mining and fishing industries. However, there seems little direct connection in Table 3 between the mix of changes and the staples industries. Beyond fish retailers, dock and wharves operators, and boat builders, specialized businesses serving the mining and fishing industries don't appear on the list.

The cost structure of business types may also influence the pattern of change. Some businesses incur relatively large cost for setting up or establishing the business. Once these costs have been met, businesses will operate as long as they cover their operating costs. These businesses require a smaller market to stay in a region than they needed to enter it. Business types that operate out of large buildings likely have large fixed costs; hospitals, theatres, and hotels were business types that increased relative to staples production and population. Agriculture producers such 
as greenhouses, dairies, and poultry breeders experienced relative growth in the number of firms and are likely to have significant entry costs.

The most probable explanation for the pattern of change found in Table 3 is that it reflects the move from a booming mining frontier to a settled territory. Settlement could be the result of the construction of the Alaska Railroad, the creation of new non-mining towns, and a change in the dominant type of mining in the territory. The relative decline in business types that serve unmarried, mobile men, such as second-hand stores, baths, reading rooms, billiard parlours, and storage facilities support this explanation. As does the relative decline in businesses associated with growth and change like house and sign painters, real estate agents, brokers, and building contractors. The business types that increased relative to the non-Indigenous population are the types that provide general services to a settled population.

Both the United States Census and the Polk Directories support the first portion of the Jack London hypothesis: "Resource development changes the support sector in ways that last beyond a particular resource boom." The census shows that, between 1910 and 1920, all support sector occupations increased their share of total employment relative to the staples industries. Comparing the 1915-1916 directory and the 1923-1924 directory showed that in over three-quarters of the business categories, the number of firms increased relative to a measure of staples activity. The decline in the support sector did not mirror the staples decline. The early twentieth century Alaska mining boom left something behind after the First World War economic bust.

The second part of the Jack London hypothesis - "and [changes the support sector in ways that] encourage future economic activity"can't be tested with this data since these results occur in the longer run. However, the examination of both the census and the Polk data suggest that what was left behind after the First World War economic bust was a more diverse, relatively larger support sector. London, as well as regional economists like Thompson (1965) and Chinitz (1961), recognized the importance of the larger more diverse support sector for entrepreneurs and workers pursuing new opportunities. Such an economy provides a large range of goods and services; the local availability reduces the cost for new businesses. The Polk results also show that for a significant number of business categories, the number of firms increased faster than population. This would mean an increase in competition in the support sector and, in theory, result in lower prices. It looks like what the boom left behind after the First World War was an Alaska that was a little less of a frontier 
with an economy better able to support a settled population and new businesses. While this isn't a test for the second part of the hypothesis, it provides a suggestion of the links between change in the support sector and economic growth.

\section{Conclusion}

The economic history of resource frontiers has often been written as a story of boom and bust. In Alaska the mining boom of the early twentieth century was brought to an end by the economic bust that commenced with the start of the First World War. The war affected the Alaska economy both directly and indirectly. The wartime inflation and the opportunities for work in the wartime industries resulted in the collapse of gold mining in the territory and the exodus of much of the non-Indigenous population. Increased problems with shipping and the delay in the construction of the Alaska Railroad magnified the economic hardship. While the copper and fishing industries prospered during the war years, both suffered decline at the end of the war. The economy remained in the doldrums until the Second World War ushered in the next Alaska economic boom.

The boom-bust story of the frontier economy assumes the economy is fragile. Frontier economic growth mirrors the growth of its staples production, which depends on external markets and natural conditions. The end of staples production in this story meant the end of the economy. Observing the Klondike Gold Rush, Jack London concluded that the frontier economies might be less fragile than usually assumed. He suggested that staples economic booms might leave something behind after the staples sector declines. Some firms in the supporting industries attracted to a region by the resource boom may stay behind after the bust. London predicted that the remaining businesses and infrastructure would create future economic opportunities.

The Jack London hypothesis can be stated as "Resource development changes the support sector in ways that last beyond a particular resource boom and encourage future economic activity." This first part of the hypothesis was tested by comparing the changes in the support sector of the Alaska economy to changes in the overall economy and its staples component. The 1910 and 1920 United States Census and the 1915-1916 and 1923-1924 Polk Directories provided data for the test. The pattern of change in the support sector in response to the decline in the staples industries after the First World War was consistent with the first part of the hypothesis. Decline in support sector industries did not mirror the 
decline in the staples industries. As London predicted, the support sector was changed in ways that lasted beyond the resource boom.

Economic resilience in northern resource-based economies is still a concern. Northern communities often see mineral or petroleum production as the only opportunity for economic growth (Southcott 2015). However, since the resources are finite, this development comes with an eventual end. The boom-bust story predicts that finite resources place a limit to the growth of the local economy. The Jack London hypothesis presents the possibility of a more optimistic post-resource-boom story. Structural changes that occur during the resource booms may change the economic environment in ways that promote future opportunities. Local policymakers may wish to pay attention not simply to resource development but also to the part of the economy that is left behind after the boom.

\section{Author}

Lee Huskey is emeritus professor of economics at the University of Alaska Anchorage.

\section{Notes}

1. The mining and manufacturing sectors fell by even more. The staples decline was moderated by a $16 \%$ increase in the fisheries, farming, and forestry sector. This increase between 1910 and 1920 may have been an aberration that resulted from the timing of the census canvass and the seasonal nature of the fisheries. As described above, the fisheries industry had limited impact on the local economy and it was on the cusp of entering its own recession in the 1920s.

2. Unfortunately, the occupational detail is not complete or consistent between 1910 and 1920. The 1920 census provides information on many more detailed occupations. The information in Table 1 describes the growth for those occupations that were reported in both 1910 and 1920.

3. As with the census data, a relative increase in the number of firms means either the number of firms actually increased or the number of firms declined at a lower rate than the overall economy or the staples sector.

4. The value of minerals produced in Alaska was \$19,547,292 in 1913 and $\$ 20,330,643$ in 1923 (Smith, 1930). This was deflated using the United States Consumer Price Index (Minneapolis Federal Reserve, 2016). The value of real mineral production fell from $\$ 33,763,504$ in 1913 to $\$ 20,330,643$ in 1923 using an index with base year 1923. Using the same methodology between 1915 and 1923 produces a decline of 60\%. 


\section{References}

Belich, J. 2010. “Exploding Wests: Boom and Bust in Nineteenth Century Settler Societies." In Natural Experiments of History, edited by J. Diamond and J.A. Robinson, 53-87. Cambridge: Harvard University Press.

Chinitz, B. 1961. "Contrasts in Agglomeration: New York and Pittsburgh." The American Economic Review 51, No. 2 (May): 279-289.

Cole., T., and E. E. Rasmuson. 2000. Banking on Alaska: The Story of the National Bank of Alaska, Vol. 1. Anchorage: National Bank of Alaska.

Handel, R. 1975. "Profiles of Small Urban Area Change." In A Numerator and Denominator for Measuring Change, Technical Paper 37. Washington, DC: The Census Bureau, US Dept. of Commerce.

Haycox, S. 2002. Alaska: An American Colony. Seattle: University of Washington Press.

Jones, P. 2010. City for Empire, an Anchorage History, 1914-1941. Fairbanks: University of Alaska Press.

Krikelas, A. 1992. "Review of Economic Base Literature." Economic Review Jul/Aug: 13-31. Federal Reserve Bank of Atlanta.

Library and Archives Canada. 2015. "History of Directory Publishing." Last modified 2 Feb 2015. http://www.bac-lac.gc.ca/eng/discover/directoriescollection/Pages/directories-collection-history-publishing.aspx

London, J. 1900. “The Economics of the Klondike." The American Monthly Review of Reviews 21, No. 1: 70-74.

Minneapolis Federal Reserve. 2016. CPI Calculator Information. Accessed 26 July 2016. https://www.minneapolisfed.org/community/teaching-aids/ cpi-calculator-information/consumer-price-index-and-inflation-rates-1913

Naske, C., and H. Soltnick. 1987. Alaska, A History of the $49^{\text {th }}$ State. Norman: University of Oklahoma Press.

Polk, R.L. 1916. Polk's 1915-16 Alaska Yukon Gazetteer and Business Directory. R.L. Polk and Co. Seattle.

Polk, R.L. 1924. Polk's 1923-24 Alaska Yukon Gazetteer and Business Directory. R.L. Polk and Co. Seattle.

Rogers, G. 1962. The Future of Alaska, the Economic Consequences of Statehood. Baltimore: The Johns Hopkins Press.

Smith, P. 1930. “Mineral Industry of Alaska in 1930.” US Geological Survey. Washington, DC. https://pubs.usgs/bul/0783a/report.pdf

Southcott, C. 2015. "Resource Development and Northern Communities - an Introduction." The Northern Review 41: 3-12.

Thompson, W. 1968. A Preface to Urban Economics. Baltimore: The Johns Hopkins Press.

US Census Bureau. 1910. Population 1910, Vol. III. Washington, DC: US Department of Commerce. 
US Census Bureau. 1920. Population 1920, Vol. IV. Washington, DC: US

Department of Commerce.

Walton, G., and H. Rockoff. 2010. History of the American Economy. Mason, Ohio: Southwestern Cengage Learning. 